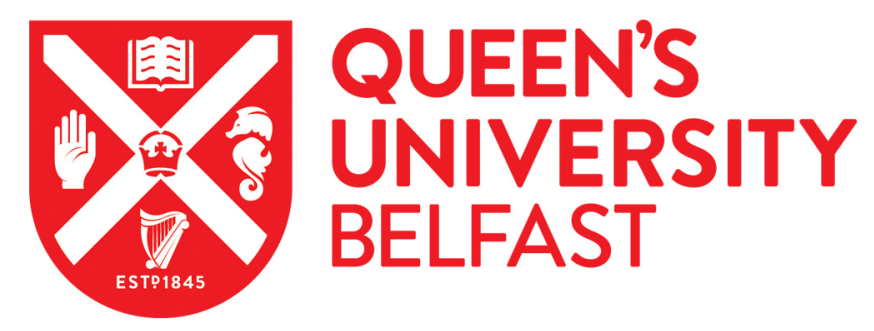

\title{
Knowledge stocks, knowledge flows and innovation: Evidence from matched patents and innovation panel data
}

Roper, S., \& Hewitt-Dundas, N. (2015). Knowledge stocks, knowledge flows and innovation: Evidence from matched patents and innovation panel data. Research Policy, 44(7), 1327-1340.

https://doi.org/10.1016/j.respol.2015.03.003

\section{Published in:}

Research Policy

Document Version:

Peer reviewed version

Queen's University Belfast - Research Portal:

Link to publication record in Queen's University Belfast Research Portal

Publisher rights

(c) 2015, Elsevier B.V. Licensed under the Creative Commons Attribution -NonCommercial-NoDerivs License

(https://creativecommons.org/licenses/by-nc-nd/4.0/), which permits distribution and reproduction for non-commercial purposes, provided the author and source are cited.

\section{General rights}

Copyright for the publications made accessible via the Queen's University Belfast Research Portal is retained by the author(s) and / or other copyright owners and it is a condition of accessing these publications that users recognise and abide by the legal requirements associated with these rights.

Take down policy

The Research Portal is Queen's institutional repository that provides access to Queen's research output. Every effort has been made to ensure that content in the Research Portal does not infringe any person's rights, or applicable UK laws. If you discover content in the Research Portal that you believe breaches copyright or violates any law, please contact openaccess@qub.ac.uk. 


\title{
Knowledge stocks, knowledge flows and innovation: Evidence from matched patents and innovation panel data
}

\author{
Stephen Roper * and Nola Hewitt-Dundas ** \\ * Enterprise Research Centre and Warwick Business School, University of Warwick, \\ Coventry, CV4 7AL, UK \\ Email: Stephen.Roper@wbs.ac.uk \\ ** School of Management, Queen's University Belfast, BT7 1NN \\ Email:nm.hewitt@qub.ac.uk
}

\begin{abstract}
Successful innovation depends on knowledge - technological, strategic and market related. In this paper we explore the role and interaction of firms' existing knowledge stocks and current knowledge flows in shaping innovation success. The paper contributes to our understanding of the determinants of firms' innovation outputs and provides new information on the relationship between knowledge stocks, as measured by patents, and innovation output indicators. Our analysis uses innovation panel data relating to plants' internal knowledge creation, external knowledge search and innovation outputs. Firm-level patent data is matched with this plant-level innovation panel data to provide a measure of firms' knowledge stock. Two substantive conclusions follow. First, existing knowledge stocks have weak negative rather than positive impacts on firms' innovation outputs, reflecting potential corerigidities or negative path dependencies rather than the accumulation of competitive advantages. Second, knowledge flows derived from internal investment and external search dominate the effect of existing knowledge stocks on innovation performance. Both results emphasise the importance of firms' knowledge search strategies. Our results also reemphasise the potential issues which arise when using patents as a measure of innovation.
\end{abstract}

Acknowledgements: We are grateful for valuable comments on earlier drafts from participants in a seminar at the Manchester Institute for Innovation Research, the DRUID Conference June 2011, Copenhagen and the AIE conference, Beijing, June 2011. The paper was further improved by detailed comments from the editor and two referees from this journal. Remaining errors are our own.

Keywords: Innovation, knowledge stocks, patents, Ireland 


\section{Knowledge stocks, knowledge flows and innovation: Evidence from matched patents and innovation panel data}

\section{Introduction}

Successful innovation depends on knowledge - technological, strategic and market related. In this paper we explore the role of existing knowledge stocks and current knowledge flows in shaping innovation success. Existing knowledge stocks may, for example, contribute directly to the novelty or complexity of new innovation (Lee 2010). They may also shape firms' investments in internal knowledge creation and external knowledge search, emphasising or de-emphasising particular technologies or knowledge-types, with potential implications for innovation outputs (Wu and Shanley 2009). Similarly, internal knowledge investments may have either a complementary or substitute relationship with external knowledge search, again with potential implications for innovation outputs (Arora and Gambardella 1990; Cassiman and Veugelers 2002).

Our analysis provides evidence on the relative impact of existing and 'new' knowledge in shaping firms' innovation trajectories. In particular, we provide a link between the growing literatures on open innovation (Chesborough 2003, 2006) and innovation partnering (Oerlemans et al. 1998; Roper 2001; Love and Roper 2004), which emphasise current knowledge flows, and other studies which emphasise the innovation impacts of knowledge stocks (Brouwer and Kleinknecht 1999; Park and Park 2006). Our analysis also contributes to our understanding of what Wu and Shanley (2009) call the 'competence-rigidity paradox' reflecting the ambiguity of resource-based and managerial perspectives on the relationship between knowledge and innovation. For example, resource-based perspectives on the firm suggest that existing knowledge resources will be positively related to innovation and business performance (Haskel et al. 2009; Dierickx and Cool 1989). Literatures on open innovation, innovation partnerships and networks also suggest the positive innovation benefits of external knowledge flows (Fleming and Waguespack 2007; West and Gallagher 2006; Hung and Chou, 2013). Managerial perspectives, however, while recognising the potentially positive innovation effects of both existing knowledge stocks and knowledge flows, also recognise the potential for negative innovation effects through path-dependency (Thrane et al. 2010), core-rigidities (Leonard-Barton 1992), or search myopia (Levinthal and March 1993). Our analysis encompasses both of these perspectives, testing inter alia the 
interactions between existing knowledge stocks and knowledge flows arising from internal investments in knowledge creation and external search activity.

Our analysis is based on a matched database which combines firm-level patent data with panel data on individual plants' innovation activity derived from a series of surveys of Irish manufacturing plants (Hewitt-Dundas and Roper 2008). The innovation panel data - the Irish Innovation Panel or IIP - also provides a wide range of other variables relating to the characteristics of each plant, their innovation partnering activities and their internal capabilities and resources (Roper et al. 2008). The combination of these two data sources enables us to examine the role of knowledge (patent) stocks in shaping innovation activity, directly addressing a gap in our understanding as identified by de Rassenfosse and van Pottlesberghe (2009). Indeed, as far as we can ascertain, this is the first time that a businessunit level analysis of this type, exploring the relationship between patent stocks and surveybased measures of innovation outputs has been possible, although other studies have considered the effect of firms' innovation strategy on patenting behaviour (Peeters and van Pottelsberghe 2006) ${ }^{1}$.

Interest in the importance of patents as a contributor to innovation has been stimulated by the sharp global increase in patenting activity over recent years. In Ireland, the number of successful patent applications to the US and European patent offices has also risen sharply over the last two decades (Figure 1), growing faster than that in the large OECD countries and most other small European countries from 1978 to 2009 (Hewitt-Dundas et al. 2014). In the pre-1990 period, patenting activity in Ireland was very limited and was dominated by applications from individual inventors. By 1998, growth in the foreign-owned sector in Ireland, driven largely by favourable corporation tax rates and relatively low labour costs, meant that foreign-owned companies accounted for 47 per cent of industrial employment, 82 per cent of industrial output and approximately 50 per cent of all Irish patent applications (McCarthy 2001) $)^{2}$. Studies have also emphasized the heterogeneity of patenting performance among Irish firms ${ }^{3}$, differences in the patenting performance of externally-owned and

\footnotetext{
${ }^{1}$ Brouwer and Kleinknecht (1999) also consider the converse relationship between innovative sales and indicators of patenting activity finding positive linkages.

${ }^{2}$ Approximately three quarters of the foreign investments over this period were US owned, concentrated in computer, chemicals, pharmaceuticals and electrical equipment sectors (McCarthy 2001; Barry 2005).

${ }^{3}$ Ramani et al. (2008) note similar heterogeneity in patenting activity in their study of biotech based foods and that this pattern of heterogeneity changes little from year to year. This reflects other studies which have
} 
indigenously-owned firms (O'Sullivan, 2000), and the relatively low level of patenting per capita in Ireland compared to the UK (Mainwaring et al. 2007) and other reference economies (Trajtenberg 2001) ${ }^{4}$. Reflecting the themes highlighted by O'Sullivan (2000) and McCarthy (2001), more recent examinations of the industrial composition of Irish patents also suggest the importance of patenting activity in those high-tech sectors in which inward investment has dominated recent development (Hewitt-Dundas et al. 2014).

The remainder of the paper is organised as follows. Section 2 sets out the conceptual basis for our analysis drawing on the literatures on open innovation and the knowledge or innovation production function. Central to our conceptualisation of knowledge stocks and flows is the asset accumulation model suggested by Dierickx and Cool (1989). Hypotheses are developed relating to the impact of existing knowledge (patent) stocks and knowledge flows on innovation. Section 3 describes our data sources and econometric methods and Section 4 summarises the key empirical results. Section 5 provides some robustness tests while Sections 6 and 7 include discussion and conclusions.

\section{Conceptual background and hypotheses}

Definitions of innovation vary, but generally stress the commercialisation of new knowledge or technology to generate increased sales or business value. The US Advisory Committee on Measuring Innovation, for example, defines innovation as: 'The design, invention, development and/or implementation of new or altered products, services, processes, systems, organisational structures or business models for the purpose of creating new value for customers and financial returns for the firm' (Advisory Committee on Measuring Innovation in the 21st Century Economy 2008, p. i). Underlying this definition is a process of knowledge transformation or codification in which innovations are developed based on firms' accumulated knowledge stocks (Hansen and Birkinshaw 2007). Such knowledge stocks represent the accumulation over time of past knowledge flows, emphasising the importance of firms' decisions about knowledge acquisition. As Diericx and Cool (1989, p. 1506) note:

highlighted the persistence of patenting activity among small numbers of firms. See Roper and Hewitt-Dundas (2008) for a discussion.

${ }^{4}$ On average each patenting firm in Ireland included in the Mainwaring et al (2007) study had an average of 4.28 patents compared to 3.25 in Wales and 4.09 in Scotland and 10.41 in England. Across the whole population of surveyed firms (4149 in Wales and 700 in the other three areas) these translate into average patent numbers per firm of: Ireland, 0.18; Wales, 0.11; Scotland, 0.26 and England, 0.61. Source: Mainwaring et al., 2007, Table 2. 
'... while flows can be adjusted instantaneously, stocks cannot. It takes a consistent pattern of resource flows to accumulate a desired change in strategic asset stocks'. Additions to firms' knowledge stocks may, however, arise from either internal or external sources, with recent studies emphasising the potential importance of external knowledge for innovation (Chesborough 2003, 2006), and the potential for external knowledge to complement firms' pre-existing knowledge stocks (Choo and Bontis 2002) and/or new internally generated knowledge flows (Zenger 2002; Cassiman and Veugelers 2002; Cassiman and Veugelers 2006).

This suggests three, potentially inter-related, sources from which firms might derive the knowledge underlying current innovation (Figure 2). First, existing knowledge stocks might provide proprietary knowledge contributing to the novelty of new innovation. As Tzabbar et al. (2008) suggest, past studies have linked knowledge stocks with technological leadership, enhanced market position and corporate performance. Empirical support for the importance of pre-existing knowledge stocks for innovation is provided both by the widespread importance of incremental innovation which builds strongly on previous innovation (Helfat 1994; Audretsch 2002) as well as evidence on the persistence of patenting and innovation (Cefis and Orsenigo 2001; Roper and Hewitt-Dundas 2008). Whether represented by codified metrics such as patent stocks, or more intangible indicators, such resources might be expected to make a positive contribution to firms' innovation outputs by accelerating innovation processes or providing the basis for increased novelty and customer satisfaction (Kyriakopoulos and de Ruyter 2004). Wu and Shanley (2009), for example, identify positive innovation output effects from both of the knowledge stock measures they consider ${ }^{5}$. This suggests Hypothesis 1 that:

H1: Existing knowledge stocks will have a positive impact on innovation outputs.

Secondly, innovation may be influenced by current knowledge flows generated through firms' investments in in-house knowledge creation through R\&D (Jordan and O'Leary 2007; Hewitt-Dundas and Roper 2009). There is widespread evidence of the positive role of such

\footnotetext{
${ }^{5}$ Teece (1998) suggests, however, that the boundary between firm's internal knowledge stock and external knowledge can be blurred. Firms do not benefit from external knowledge merely through exposure to it, but rather the benefit reflects their absorptive capacity, i.e. their ability to identify, assimilate and utilize appropriate external knowledge to complement knowledge stocks (Escribano et al. 2009).
} 
knowledge investments on innovation and business performance with Artz et al. (2010) providing a recent review. At a macro-economic level, studies such as (Guellec and van Pottelsberghe 2004) have identified the positive impact of R\&D spending on productivity growth while regional studies have also emphasized the potential value of R\&D investments (Rodriguez-Pose 2001). Similarly, sectoral studies have emphasized the positive relationship between R\&D intensity and innovation outputs across a range of high-tech (Ulku 2007) and low-tech sectors (Santamaria et al. 2009). At a firm or business-unit level, evidence of the positive innovation effect of firms' internal knowledge investments is also widespread. Artz et al. (2010), for example, explore the relationship between R\&D investment and patenting and R\&D investment and product announcements by large North American firms finding a positive relationship in each case. This suggests Hypothesis 2:

\section{H2: Knowledge flows from internal investments will have a positive impact on innovation outputs}

Firms' knowledge investments, and therefore potentially their innovation outcomes, may however be contingent on firms' existing knowledge stocks (Wu and Shanley 2009; Dierickx and Cool 1989). Dierickx and Cool (1989), for example, stress the potential for 'asset mass efficiencies' in which firms with strong knowledge stocks find it easier to add further increments to their knowledge stock. Complementarities between new knowledge and firms' existing knowledge stocks ('interconnectedness') may also add to their innovation value (Dierickx and Cool 1989; Zenger 2002). Contingency between firms' new knowledge flows and existing knowledge stocks may not always be positive, however, due to search myopia or lock-in (Leonard-Barton 1992). As Helfat (1994, p. 174) notes: 'because learning is cumulative, firms are likely to search for new products and processes in areas related to past R\&D. As a result the direction of future learning depends on the nature of the accumulated knowledge base'. Firms may also have a preference for new products or processes which are strongly related to their existing knowledge base (Thrane et al. 2010) ${ }^{6}$. Either factor may narrow the scope of firms' search for new knowledge potentially limiting the complementarities between current knowledge flows and existing knowledge stocks. Kyriakopulos and de Ruyter (2004, p. 1470), for example, cite the disk drive sector in particular as having difficulty in trying 'to break away from entrenched routines or obsolete information channels'. Other empirical evidence on the effect of knowledge stocks on the

\footnotetext{
${ }^{6}$ For example, Lucas and Goh (2009) document the resistance of Kodak to embracing digital photography despite the firms' understanding of the technologies involved.
} 
innovation benefits of knowledge investments is, to quote Wu and Shanley (2009, p. 481) 'rather limited'. However, their results for the US electro-medical device sector suggest that firms' knowledge stock moderates the innovation benefits of external knowledge search, i.e. 'a continuously increasing effort of exploration is helpful where a firm has a narrow knowledge base; however as the knowledge breadth increases a moderate level of exploration is more productive' (p. 482). This suggests:

H3: Existing knowledge stocks will have a negative moderating effect on the innovation value of knowledge flows from internal investments.

Alongside their in-house knowledge investments firms might also engage in an external search for knowledge for innovation (Figure 2). Previous studies have emphasised the value of such boundary-spanning knowledge flows for innovation (Oerlemans et al. 1998; Love and Roper 2001) as well as the potential limits of external knowledge acquisition (Laursen and Salter 2006). Knowledge obtained from customers, for example, might impact most strongly on incremental product innovation ( $\mathrm{Su}$ et al. 2007), while knowledge provided by suppliers or external consultants might impact most directly on process change (Horn 2005; Smith and Tranfield 2005) or new-to-market product innovation. There is increasing evidence, however, that this effect is non-linear. Wu and Shanley (2009) working with patent citation data, identify an inverted ' $U$ ' shape relationship between new patent citations and successful patent applications in the US electromechanical device industry. Similarly, Laursen and Salter (2006) and Katila and Ahuja (2002) also find an inverted 'U' shape relationship between firms' innovation performance and external search effort. As indicated in Figure 2 this suggests Hypothesis 4:

H4: Knowledge flows from external knowledge search will have a positive but nonlinear impact on innovation outputs.

As with firms' in-house knowledge investments, however, the innovation value of externally sourced knowledge may also be contingent on firms' existing knowledge stocks and their potential for shaping the focus or intensity of external knowledge search (Hung and Chou 2013; Wu and Shanley, 2010). Again, 'asset mass efficiencies' or 'interconnectedness' between existing knowledge stocks and external knowledge flows may be important (Dierickx and Cool 1989), with Wu and Shanley (2009) also suggesting that external knowledge search may also contribute to innovation by helping firms to access new 
knowledge and technology, particularly in highly turbulent technological environments (Hung and Chou 2013, Bergek et al. 2013) and potentially avoiding core-rigidity or negative path dependency (Leonard-Barton 1992). Penin (2005) also argues that existing knowledge (patent) stocks may also ease collaboration among companies by providing a transparent basis for collaboration or partnership. Negative effects might also be anticipated, however, where external search activity is disproportionate in scale, overly costly, disruptive or where the technologies accessed are more distant from firms' existing technological competencies (Ahuja and Katila 2001). As with internal knowledge investments, we therefore anticipate that:

H5: Existing knowledge stocks will have a negative moderating effect on the innovation value of knowledge flows from external search.

Finally, there may also be complementarity between flows of internally generated and externally sourced knowledge (e.g. Arora and Gambardella, 1990; Veugelers and Cassiman, 1999; Cassiman and Veugelers, 2006). Firms' internal investments in R\&D, for example, have often been seen as important to absorptive capacity (Cohen and Levinthal 1990; Zahra and George 2002) allowing firms: to scan for the best available external knowledge; to enable the efficient absorption and use of this knowledge; and, to help in the appropriation of the returns from new innovations (Griffith et al. 2003). Internal R\&D may, for example, help firms to minimise asymmetric information with technology suppliers and so reduce uncertainty and the transaction costs and other strategic issues associated with external knowledge search (Teece, 1988). This suggests:

H6: Knowledge flows from internal investments and external search will have complementary impacts on innovation.

\section{Data and methods}

Our empirical analysis is based on matched data taken from two sources. Data from the Irish Innovation Panel (IIP) is used to measure plants' innovation activity, knowledge flows from in-house investment and external knowledge search, and a range of control variables. Patent histories derived from the US and European patent offices are used to reflect firms' existing 
stocks of codified, inimitable knowledge which may provide the basis for novel innovation and, potentially, shape the innovation value of current knowledge flows (Penin, 2005).

The Irish Innovation Panel provides information on Irish manufacturing plants' technology adoption, networking and performance over the period 1991 to 2008. More specifically, the IIP comprises six sample surveys or waves conducted using similar survey methodologies and questionnaires with common questions (Roper et al. 1996; Roper and Hewitt-Dundas 1998; Roper and Anderson 2000; Hewitt-Dundas and Roper 2008). Each of the six surveys covers the innovation activities of manufacturing plants in Ireland with 10 or more employees over a three-year reference period ${ }^{7}$. The resulting panel is highly unbalanced reflecting randomised sampling, non-response in individual surveys but also the opening and closure of plants over the 18 year period covered ${ }^{8}$. Analyses suggest that non-response bias in each survey is limited and each wave of the IIP can therefore be considered as representative of the underlying target population of manufacturing firms (Roper and Anderson 2000; Roper, Hewitt-Dundas, and Savage 2003).

Plants' innovation activity in the IIP is represented by three variables intended to reflect different aspects of innovation performance. First, a simple binary indicator is used to reflect whether or not a plant had introduced any new or improved products during the previous three years. At plant level this indicator provides a baseline measure of engagement with product innovation; at a population level the indicator reflects the extent of product innovation activity (Figure 3, part A). A similar binary indicator is used to reflect the extent of process innovation (Figure 3, part A). The third innovation output measure is the proportion of plants' total sales (at the end of each three-year reference period) derived from products newly introduced during the previous three years. This variable reflects not only

\footnotetext{
${ }^{7}$ The initial IIP survey, undertaken between October 1994 and February 1995, related to plants' innovation activity over the 1991-93 period, and achieved a response rate of 32.0 per cent (Roper et al., 1996; Roper and Hewitt-Dundas, 1998, Table A1.3). The second IIP survey was conducted between November 1996 and March 1997, covered plants' innovation activity during the 1994-96 period, and had a response rate of 28.6 per cent (Roper and Hewitt-Dundas, 1998). The third IIP survey covering the 1997-99, period was undertaken between October 1999 and January 2000 and achieved an overall response rate of 29.4 per cent (Roper and Anderson, 2000). The fourth survey was undertaken between November 2002 and May 2003 and achieved an overall response rate of 29.0 per cent. The fifth wave of the IIP, conducted between January and June 2006, had an overall response rate of 32.0 per cent. The postal element of the sixth wave of the IIP was conducted between April and July 2009 with subsequent telephone follow-up and achieved a response rate of 38.8 per cent.

${ }^{8}$ Plants are only included in the survey if they have been established for three or more years. This excludes very young firms from the survey for which all products are likely to be innovative. In fact, 5.6 per cent of the estimation sample had been established for 5 years or fewer at the time of the survey, 16.4 per cent had been established for 10 years or fewer.
} 
plants' ability to introduce new products to the market but also their short-term commercial success. Across the IIP, 64.1 per cent of plants were product innovators while 58.1 per cent were process innovators; 14.7 per cent of plants' sales were derived from newly introduced products (Table 1). Correlations between the innovation output variables are positive with 70.6 per cent of product innovators also engaged in process innovation activity (Table 2).

The IIP also provides information on a number of other plant characteristics which previous studies have linked to innovation outputs. For example, across the panel, 48.5 per cent of plants were undertaking investments in in-house $R \& D$, providing our measure of knowledge flows from in-house investments in knowledge creation (Table 1). Knowledge flows arising from external search we measure using a breadth index similar to that proposed by Lausen and Salter (2006) which reflects the number of different partner types with which firms had innovation cooperation. This measure - widely used in the innovation studies literature provides an indication of the diversity and range of knowledge sources with which plants are interacting as part of their innovation activity. On average, plants were engaged in external knowledge search with 1.34 partner types (Table 1). Correlations between in-house R\&D and other innovation partnering relationships are positive (Table 2) suggesting potential complementarity between knowledge flows arising from internal R\&D invesments and external knowledge search (Arora and Gambardella 1990; Belderbos et al. 2006; Cassiman and Veugelers 2006). Other resource indicators are included in our estimation to control for the potential impact on innovation of the strength of plants' internal resource base. First, we include two indicators reflecting firms' strategic orientation: a dummy variable indicating whether or not a firm was exporting; and, a dummy variable indicating whether a firm had a formally constituted R\&D department. Both we expect to have a positive effect on innovation outputs. Secondly, we include variables which give a quantitative indication of the scale of plants' resources - e.g. size - as well as other factors which might suggest the quality of plants' in-house knowledge base - e.g. multi-nationality and vintage. Multi-nationality is included here to reflect the potential for intra-firm knowledge transfer between national markets and plants (O'Sullivan 2000), while vintage is intended to reflect the potential for cumulative accumulation of knowledge capital by older plants (Klette and Johansen 1998), or plant life-cycle effects (Atkeson and Kehoe 2005). We also include a variable reflecting the proportion of each plant's workforce which have a degree level qualification to reflect potential labour quality impacts on innovation (Freel 2005; Leiponen 2005) or absorptive capacity. Finally, studies of the impact of publicly funded R\&D have, since Griliches (1995), 
repeatedly suggested that government support for $R \& D$ and innovation can have positive effects on innovation activity both by boosting levels of investment (Hewitt-Dundas and Roper 2009) and through its positive effect on organisational capabilities (Buiseret et al. 1995). Here, we therefore include dummy varibles to indicate a range of public investments in plants' technological and human resources, largely due to the EU Objective 1 status of Ireland through much of the sample period (Meehan 2000; O'Malley et al. 2008).

Patent data for Ireland was compiled by identifying all patents where an Irish-resident was identified as an inventor, and which were granted between 1976 and 2009 by the US Patent and Trademark Office (USPTO) and/or the European Patent Office (EPO) (Hewitt-Dundas et al. 2014). For each patent award, information on the foreign priority was also collated. Foreign priority indicates if the patent application for the same invention had been made previously and where this was found to be the case then only the first patent award was included in the database. Patent assignees were matched by firm name and where possible location, with plants included in the IIP. This allowed us to compile patent histories for all Irish firms which have any plants within the IIP. One issue here is that the IIP - our innovation panel data - is plant level, while the patent data is firm level. For smaller, singleplant firms this distinction is unimportant but for larger multi-plant firms there is a more significant misalignment. We adopt the simplest possible solution, and where multiple plants in the IIP were part of the same firm, match each plant with the same, firm-level, patent history. The implicit assumption being that at the point a patent application was made the technology involved was available to all plants in the firm ${ }^{9}$.

From the patent history for each plant we then construct a depreciated patent stock measure to reflect each plant's unique and cumulated knowledge stock allowing for 'asset erosion' (Ramani et al. 2008; Dierickx and Cool 1989) ${ }^{10}$. As a first step it is useful to consider constructing an aggregate patent stock in period $t$ defined as the cumulative number of successful patent applications from the start of our data collection period (1976) to t-1. For example, for Wave 4 of the IIP which relates to innovation activity over the 2000 to 2002 period the aggregate patent stock would be measured in 1999. Measured across the IIP as a whole this aggregate patent stock measure averages 0.362 patents per firm (Table 1). As Park

\footnotetext{
${ }^{9}$ This affects only around 1 per cent of plants in each wave of the IIP.

${ }^{10}$ In our initial experiments we also considered the un-depreciated patent stock for each plant, and a patent flow measure intended to represent firms' contemporaneous engagement with patenting. Both generated very similar results to those presented later in the paper.
} 
and Park (2006) highlight, however, this type of a patent stock definition does not allow for the potential depreciation of patented knowledge which might be expected to be more rapid in high-tech industries. Applying their estimated depreciation rates for each industry, which vary from 17.89 per cent for office machinery and computers to 11.86 per cent for tobacco products, allows us to calculate a depreciated patent stock variable for each plant observation in the $\mathrm{IIP}^{11}$. On average across the IIP, the depreciated patent stock has an average of 0.153 per firm or 0.131 per 100 employees (Table 1). As Mainwaring et al. (2007) emphasise, however, the distribution of patent activity is diverse with 'very few firms patent-active and many of these are single-patent firms' (p. 1663). Over the whole IIP an average of 5.0 per cent of firms had made successful patent applications although, reflecting the national trend, this figure rose from 2.1 per cent in the 2001 to 2003 period to 8.2 per cent in the 2006 to 2008 period $^{12}$.

Our empirical approach focuses on the innovation or knowledge production function which represents the process through which pre-existing knowledge stocks and current knowledge inputs are transformed into innovation outputs (Griliches 1995; Love and Roper 2001; Laursen and Salter 2006). This approach has been widely used in the innovation studies literature, and the innovation or knowledge production function forms an element of the widely used CDM modelling framework (Crepon et al. 1998). In more formal terms, if $\mathrm{I}_{\mathrm{i}}$ is an innovation output indicator for plant $i$ the innovation production function might then be summarised as:

$$
I_{i}=\beta_{0}+\beta_{1} K S_{i}+\beta_{2} K I_{i}+\beta_{3} K S_{i} \times K I_{i}+\beta_{4} K X_{i}+\beta_{5} K S_{i} \times K X_{i}+\beta_{6} K I_{i} \times K X_{i}+\beta_{7} R I_{i}+\delta_{i}
$$

Where: $\mathrm{KI}_{\mathrm{i}}$ are plants' internal knowledge investments, $\mathrm{KX}_{\mathrm{i}}$ are plant i's external knowledge search, $\mathrm{KS}_{\mathrm{i}}$ is the existing knowledge stock and $\mathrm{RI}_{\mathrm{i}}$ is a set of plant-level control variables.

\footnotetext{
${ }^{11}$ By industry the patent depreciation rates calculated by Park and Park (2006) are: Food products and beverages, 11.88; Tobacco, 11.86; Textiles, 13.09; Clothing, 13.85; Tanning and leather, 12.69; Wood and products of wood, 12.29; Paper and paper products, 12.02; Printing, 13.97; Coke and refined mineral products, 12.63; Chemicals and chemicals products, 13.11; Rubber and plastics, 12.52; Other non-metallic minerals, 12.84; Basic metals, 12.61; Fabricated metal products, 12.52; Machinery and equipment, 12.76; Office accounting and computing, 17.89; Electrical machinery and apparatus, 14.39; Radio tv and communications, 16.08; Medical precision and optical , 13.93; Motor vehicles , 13.72; Other transport equipment , 13.21; Furniture, 12.44; Recycling, 13.35. Source: Park and Park (2006), Table 1.

${ }^{12}$ For individual waves of the IIP the proportion of firms with patents were: Wave 1 (1991-93), 2.1 per cent; Wave 2 (1994-96), 4.4 per cent; Wave 3 (1997-99) 4.9 per cent; Wave 4 (2000-02), 5.5 per cent; Wave 5 (200305), 6.4 per cent; Wave 6 (2006-08), 8.2 per cent.
} 
Our primary interest here is in the coefficients $\beta_{1}$ to $\beta_{6}$ which relate directly to the hypotheses outlined in the previous section.

Within $\mathrm{RI}_{\mathrm{i}}$ we include a range of variables which have been shown to influence innovation outputs in previous studies involving innovation production functions (Crepon et al. 1998; Loof and Heshmati 2001, 2002; Roper et al. 2008). First, we include variables relating to exporting and the organisation of R\&D to reflect firms' strategic orientation. Secondly we include a variable to reflect plant size which we interpret in the Schumpeterian tradition as a resource indicator, and which has been shown in previous studies to have a typically nonlinear (inverted-U shape) relationship to innovation outputs (Jordan and O’Leary 2007). Thirdly, we include an indicator of enterprise vintage to capture potential firm life-cycle effects (Atkeson and Kehoe 2005). Fourth, we include an indicator of whether or not a plant is externally-owned to reflect the potential for intra-firm knowledge transfer (Jensen 2004). Fifth, we include an indicator of the level of graduate skills in the plant which we expect to have a positive relationship to innovation outputs (Freel 2005; Arvanitis et al. 2007). Finally, we include an indicator of whether or not the plant had received public support for its product or process innovation activity. In each case we anticipate this support having positive effects on innovation outputs (Hewitt-Dundas and Roper 2009).

Our estimation approach is dictated largely by the fact that we are using plant data from a highly unbalanced panel and that our dependent variables are not continuous. We therefore make use of panel data probit and tobit estimators, including in each model a set of sector controls at the 2- digit level and a series of time dummies to pick up any secular differences between the waves of the IIP ${ }^{13}$. Probit models are used to model the probability that plants will engage in either product or process development. Tobit models are used where the dependent variable is the percentage of sales derived from innovative products, a variable which is truncated at zero and 100. Plant observations are also weighted to provide representative results and take account of the structured nature of the IIP surveys. Postestimation issues arise in the derivation of appropriate marginal effects in both the probit and tobit models given the inclusion of squared terms (on knowledge search) and interaction terms (Norton et al. 2004; Hoetker 2007; Berry et al. 2010). To simplify the presentation of

\footnotetext{
${ }^{13}$ We operationalize this using the xtprobit and xttobit commands within Stata. Models are estimated with random effects.
} 
the empirical results we focus here on the sign and significance of the estimated coefficients ${ }^{14}$.

\section{Empirical Results}

Estimated innovation production functions for the probability that plants undertook product innovation are included in Table 3. Five models are presented including control variables only (Model 1), control variables and the direct effects of existing knowledge stocks and knowledge flows (Models 2-4), and the complete set of interaction (moderating) effects (Model 5). Each model includes both (2-digit) industry dummy variables and time dummy variables for all except the first wave of the IIP (not reported). In Models 3 and 5 we include both the levels and quadratic of the extent of plants' external knowledge search to reflect the type of limits to external knowledge search behaviour identified by Laursen and Salter (2006).

In terms of the knowledge inputs to the probability of product innovation, knowledge flows from investments in R\&D have the anticipated significant and positive effect (Table 3). Knowledge flows from external search also have positive innovation effects, as well as the anticipated inverted ' $U$ ' shape effect on the probability of product innovation (Laursen and Salter 2006). Existing knowledge stocks, however, have an unanticipated negative but insignificant direct effect on the probability of product innovation (Table 3). Introducing the moderating effects has little impact on these direct effects, and proves significant in terms of the relationship between knowledge flows from external search and R\&D investment, and between existing knowledge stocks and knowledge flows from external search (Table 3, Model 5). The negative moderating effect between knowledge flows from R\&D investment and external search was unanticipated (Hypothesis 6), suggesting a substitute rather than complementary relationship between knowledge arising from investments and external search. We are also not alone in finding this type of substitute relationship. Laursen and Salter (2006) find a similar substitute relationship between internal R\&D and external search, arguing that it may reflect a 'not-invented-here' syndrome, or the impact of an attention allocation problem as ideas are generated both internally and externally.

\footnotetext{
${ }^{14}$ In a previous version of the paper we follow Hoetker (2007) and report average marginal effects for the variables of interest and also graphical representations of marginal effects across the range of predicted outcomes for each model (Roper and Hewitt-Dundas 2012).
} 
As suggested by Hypothesis 5, existing knowledge stocks also have a relatively weak but positive average moderating effect on the innovation value of knowledge flows derived from firms' external search activity (Table 3, Model 5). In terms of the controls, exporting, R\&D department, external-ownership and government support for innovation all have positive and significant effects on the probability of product innovation (Table 3, Model 5).

Probit models for the probability of process innovation suggest a rather similar picture to that for product innovation (Table 4). Existing knowledge stocks again have an unexpected but weak negative marginal effect on the probability of undertaking process innovation, contrary to our expectations in Hypothesis 1 (Table 4, Model 5). This contrasts strongly with the strong and positive process innovation effects of knowledge flows resulting from R\&D investment and external knowledge search, which again provide strong support for Hypothesis 2 and Hypothesis 4 (Table 4, Model 5). In terms of the moderating effects, existing knowledge stocks have no significant effects on the benefits for process innovation of knowledge flows derived from either knowledge search or investment (Model 5, Table 4). As for product innovation (Table 3) we again identify a significant substitute relationship, however, between knowledge flows derived from R\&D investments and external search (Table 4, Model 5). Here, we also find no evidence of the limits to the innovation benefits of external knowledge search identified by Laursen and Salter (2006). A number of control variables are also significant here: firm size and public support for R\&D both have positive effects; a consistent and significant negative effect on labour quality is more surprising (Table 4).

Finally, Tobit models of the proportion of sales derived from innovative products are reported in Table 5. These suggest similar positive innovation effects from knowledge flows related to search and investment to those noted earlier (Table 5, Model 5). Existing knowledge, however, again have insignificant negative effects on innovative sales (Models 2 and 5, Table 5). Including the moderating effects highlights again an unexpected (negative) substitution effect (Hypothesis 4) between knowledge flows derived from investments and external search, and a positive and significant moderating effect from knowledge stocks on the innovation value of firms' knowledge search (Hypothesis 6). Control effects here are similar to those for the probability of undertaking product innovation with R\&D department, external ownership, workforce quality and public support all having statistically significant positive effects (Table 5, Model 5). 


\section{Robustness tests}

We conduct three tests designed primarily to ensure the robustness of the sign and significance pattern of the direct effects and moderating effects of the models reported in Tables 3-5 and summarised in Table 6. One possibility is that these results are sensitive to missing values in our company survey data which restrict the estimation sample in more complex models. To test this sensitivity we re-estimated Model 5 in Tables 3, 4 and 5 (including the moderating effects) using multiple imputation for missing values (Schafer 1997). ${ }^{15}$ These models reproduce exactly the sign and significance pattern of the direct and moderating effects reported in Table 6 suggesting the robustness of the reported results.

A second possibility is that our results may reflect differences in the propensity to patent between sectors due perhaps to technological opportunities (Perez-Cano and VillenAltamirano 2013) or market entry barriers (Heger and Zaby 2013). ${ }^{16}$ To control for sectoral differences in patenting propensity we again re-estimate the final models in Tables 3, 4 and 5 including a set of interaction variables between the (firm-level) patent measure and the sectoral dummies. Including these variables has no effect on the size and significance of the direct effects of knowledge stocks, investment and search on innovation reported in Table 6. The moderating effects also remain similar in sign and significance taking identical signs across the three models. The investment-search moderating effect is unchanged from the reported models remaining negative and significant for each of the three innovation indicators (Table 6). The stock-investment interaction retains its negative sign and insignificance in the product and process innovation models and becomes negative and insignificant in the innovative sales model. Similarly, the stock-search interaction retains its sign and significance in the product innovation and innovative sales models and becomes positive and significant in the process innovation model. These results re-emphasise our key results and provide strong support for Hypothesis 2 and Hypothesis 3 but no support for our other hypotheses.

\footnotetext{
${ }^{15}$ We implement this using the MI procedure in Stata and impute missing variables on the basis of sector and the survey wave. Full details of these models and other models described in this section are available from the authors on request.

${ }^{16} \mathrm{We}$ are grateful to an anonymous referee for highlighting this potential issue and also for their suggested approach to testing the robustness of our results.
} 
Finally, we experimented with an alternative dependent variable - the number of new or improved products - which is available within the Irish Innovation Panel. This count variable takes value zero where a firm is a non-innovator, and positive integer values where a firm was innovating ${ }^{17}$. Estimating zero-inflated negative binomial models again suggests very similar results to those reported in Table 6 . Knowledge stocks have a (significant) negative effect on the number of new/improved products introduced, while R\&D and search have positive effects. In this sense our results differ from those of Artz et al. (2010) who find a positive relationship between patenting activity and the number of new product announcements in their study of larger US firms. Moderating effects follow the same pattern of sign and significance as those reported in Table 6 with the stock-search interaction again positive and significant. These results again provide support for Hypothesis 2 and Hypothesis 3 only.

\section{Discussion}

Our results provide no support for the anticipated positive effect from existing knowledge (patent) stocks on innovation outputs envisaged in Hypothesis 1 (Table 6). Instead, our evidence suggests a statistically weak negative effect between firms' knowledge (patent) stocks and each of our innovation output measures. The lack of any very clear linkage between patent stocks and innovative sales is perhaps not unsurprising given evidence since Mansfield (1986, p. 180) that the effects of the patent system 'are very small in most of the industries we studied ... very few additional inventions were commercially introduced because of patent protection, according to the firms themselves'. More recently, Faber and Hensen (2004) examine the relationship between patents granted and sales of innovative products in a group of European economies and are able to find no significant relationship ${ }^{18}$. By way of explanation they conclude that: 'the national institutional and economic infrastructure conditions shape the innovation activities carried out at the level of firms and supersede the effects of these activities on national patent acquisition'(Faber and Hensen 2004, p. 205-06). More surprising is the (albeit weak) negative relationship between existing knowledge (patent) stocks and innovation outputs rather than any more positive resourcebased or competence effect (Tzabbar et al. 2008), although Artz et al. (2010) also identify a negative relationship between patents and measures of business performance. One possibility

\footnotetext{
${ }^{17}$ This variable has mean value of 20.03 ( $\left.\mathrm{sd}=123.1\right)$ and takes value zero in 35.9 per cent of cases.

${ }^{18}$ Interestingly, in the initial models reported by Faber and Hensen (2004) patents granted has an unexpected negative effect on the relative sales of innovative products at national level.
} 
here is a misalignment effect with plants potentially devoting too many resources to the technological investments which may develop, protect or defend patents rather than effective commercialisation. Or, in terms of March (1991) placing too much emphasis on exploration rather than exploitation. Other potential explanations relate to negative path-dependency (Thrane et al. 2010) or core-rigidities (Leonard-Barton 1992) in which prior patent stocks become a constraint rather than an enabler of plants' innovation activity. For example, in some of the cases discussed by Leonard Barton (1992) managers reacted to internal tensions caused by mismatches between existing and new knowledge by abandoning difficult development projects. In other cases, similar tensions led to isolationist strategies by different groups. Both negatively influenced firms' innovation performance.

Our results suggest, as anticipated from previous studies, positive impacts from knowledge flows associated with investments in $R \& D$ on each measure of innovation providing consistent support for Hypothesis 2. That is, plants' engaging in in-house R\&D had both a higher probability of making product and process innovations and were also more likely to achieve higher levels of innovative sales. This reflects results from a range of prior studies suggesting a similar positive relationship (Ulku 2007; Santamaria et al. 2009; Artz et al. 2010). More interesting perhaps is the pattern of effects we observe for the innovation effect of knowledge flows derived from external search. These have a positive impact on both the probability of innovating and innovation success, although with evidence of diminishing returns in terms of the probability of undertaking product innovation (Table 6). Unlike Laursen and Salter (2006), however, we do not find any evidence of significant diminishing returns to search breadth for innovative sales. More broadly, therefore our results confirm the importance of knowledge flows derived from external knowledge search for innovation, and the innovation value of openness (Chesborough 2003, 2006).

Taken together our results provide some insight into the relative importance of existing knowledge stocks and current knowledge flows (from investment and external search) for innovation performance. In particular, our results emphasise the dominant importance of knowledge flows derived from plants' current knowledge investment and search activities for innovation rather than any cumulative process in which innovation draws strongly on prior knowledge investments (Dierickx and Cool 1989). Moderating effects, arising from the interaction of existing knowledge stocks and knowledge flows also prove interesting and 
perhaps help to address the concerns raised by Hutzschenreuter and Israel (2009) in their review of dynamic strategy, for example, that 'path dependencies are the least studied to date ... the empirical studies we have uncovered still fall short in accounting for the performance implications' (p. 448). Specifically, we find little evidence of any significant moderating effects between plants' existing knowledge (patent) stocks and the innovation value of current knowledge investments (Table 6). There is evidence, however, that existing knowledge stocks do have a positive effect on the innovation value of knowledge flows related to external search (Table 6). This consistent with the evidence cited in Penin (2005) which suggests that the primary contribution of patents to innovation may be through their facilitation of knowledge co-ordination between firms rather than their more direct technological effects.

Perhaps more surprisingly we also find consistent evidence of a negative moderating effect between knowledge flows derived from plants' internal R\&D investments and external search (Laursen and Salter 2006). While consistent with a resource-based view, in which knowledge derived from external search and internal investment might be substitutes, this result contrasts with much of the recent empirical literature which emphasises instead complementarities between firms' internal and external knowledge resources (e.g. Arora and Gambardella, 1990; Veugelers and Cassiman, 1999; Cassiman and Veugelers, 2006).

\section{Conclusions}

Four substantive conclusions stem from our analysis. First, across manufacturing as a whole, patent stocks have a (weak) negative rather than positive impact on plants' innovation outputs, reflecting potential negative path dependency or core-rigidities (Leonard-Barton 1992) rather than any positive accumulation of knowledge (Dierickx and Cool 1989). Second, knowledge flows associated with plants' current knowledge search and investment activities dominate any legacy effects on innovation performance. Third, while existing knowledge stocks have little direct effect on innovation outputs, they do have a positive moderating effect on the innovation value of external knowledge search (Penin, 2005). This emphasises the importance of a contextualised view of firms' knowledge acquisition strategies and the importance of allowing for existing knowledge stocks in considering the innovation effects of current knowledge acquisition. Fourth, allowing for existing knowledge stocks also suggests 
a substitution relationship between knowledge flows derived from R\&D investments and external search.

In strategic terms our results suggest the primary importance of firms' current knowledge acquisition strategy in influencing innovation, with key choices around internal R\&D investment and external search. These are alternatives, however, with - at the margin evidence of the substitutability of knowledge flows derived from external search for those derived from internal investment. Given this substitutability firms may, at the margin, have a preference for internal R\&D investment, as this may add more directly to firms' knowledge stocks and help to increase the innovation value of future knowledge search.

In terms of the measurement of innovation, our results reinforce the conclusion of Peeters and van Pottlesberghe (2006) who suggest that 'when using patent-related indicators of innovation, researchers should be aware and explicitly take into account the fact that the empirical results not only refer to a particular type of firms and sectors but also to a specific set of innovation strategies'. Indeed, our results suggest that there may actually be an inverse relationship between patent indicators and innovation output measures reflecting other similar findings in terms of between patents and measures of business performance (Artz et al. 2010). This has clear implications too for debates about the value or otherwise of current IP regulations although as Penin (2005) notes such debates need to reflect both the direct innovation effects of patents as well as their broader enabling impacts.

Our study is, of course, not without its limitations. Predominant among these is that it is restricted to manufacturing firms, while the majority of economic activity relates to services. However, it is perhaps in manufacturing where the strongest links might be expected between codified knowledge stocks - such as patents - and innovation outputs. For services, future studies might usefully explore tacit knowledge stocks and innovation. A further question relates to the generalisability of our analysis which is based on Irish data. While EU comparisons tend to emphasise the similarity of innovation behaviours in Ireland to those in other EU economies and the US (Roper et al. 2008) national factors cannot, of course, be ruled out and international replication would therefore be valuable. Finally, our measurement of knowledge stocks here using patents data is clearly limited, particularly in more traditional manufacturing sectors. Confirmatory analysis could therefore usefully be developed using 
other more broadly based knowledge stock indicators reflecting perhaps cumulated investments in R\&D and/or other intangibles (Haskel et al. 2009). 
Figure 1: Successful patent applications in Ireland: By IIP Survey period

\section{A: Patent Applications}

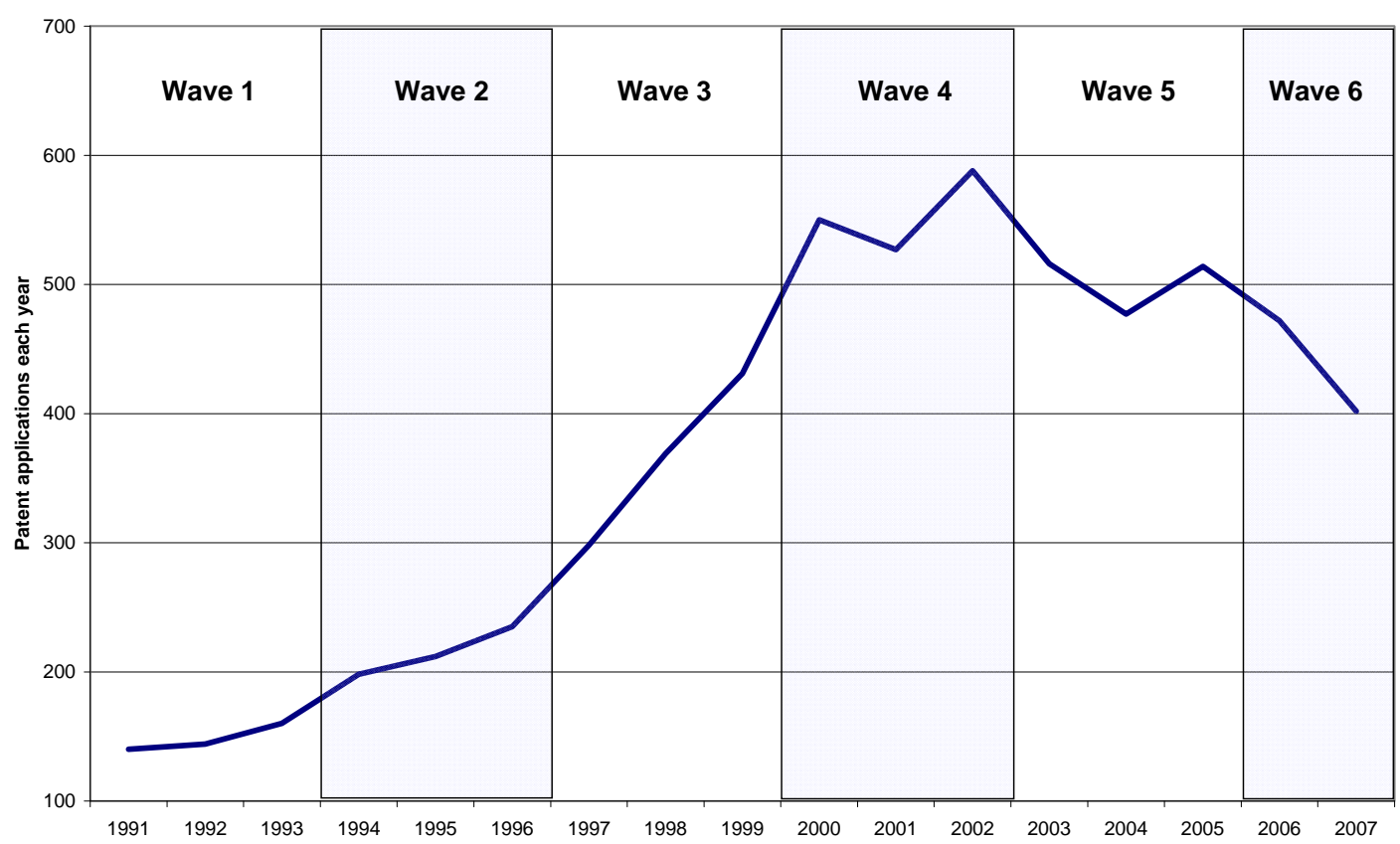

B: Patent Stock

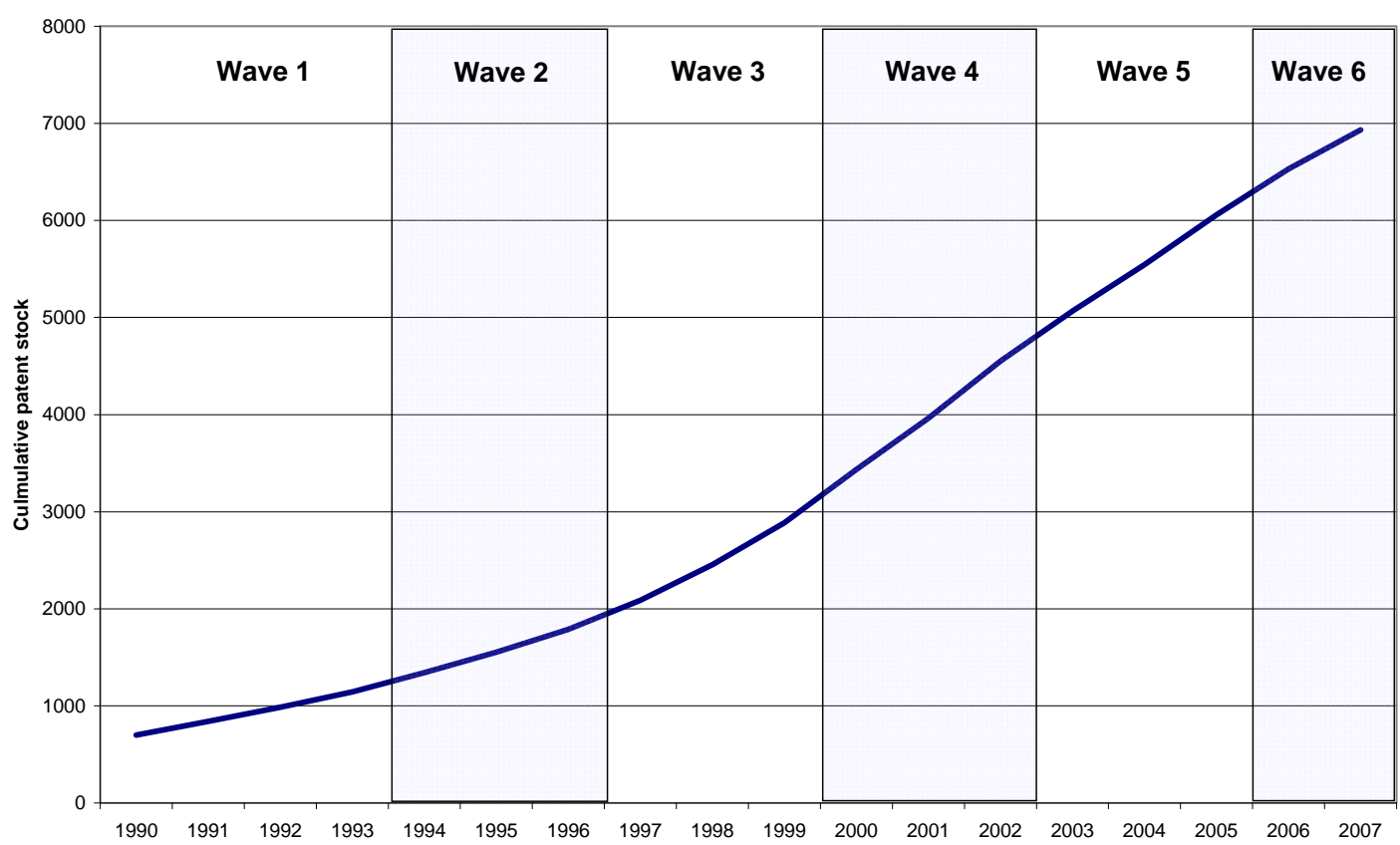

Source: Hewitt-Dundas et al., 2010 
Figure 2: Hypotheses

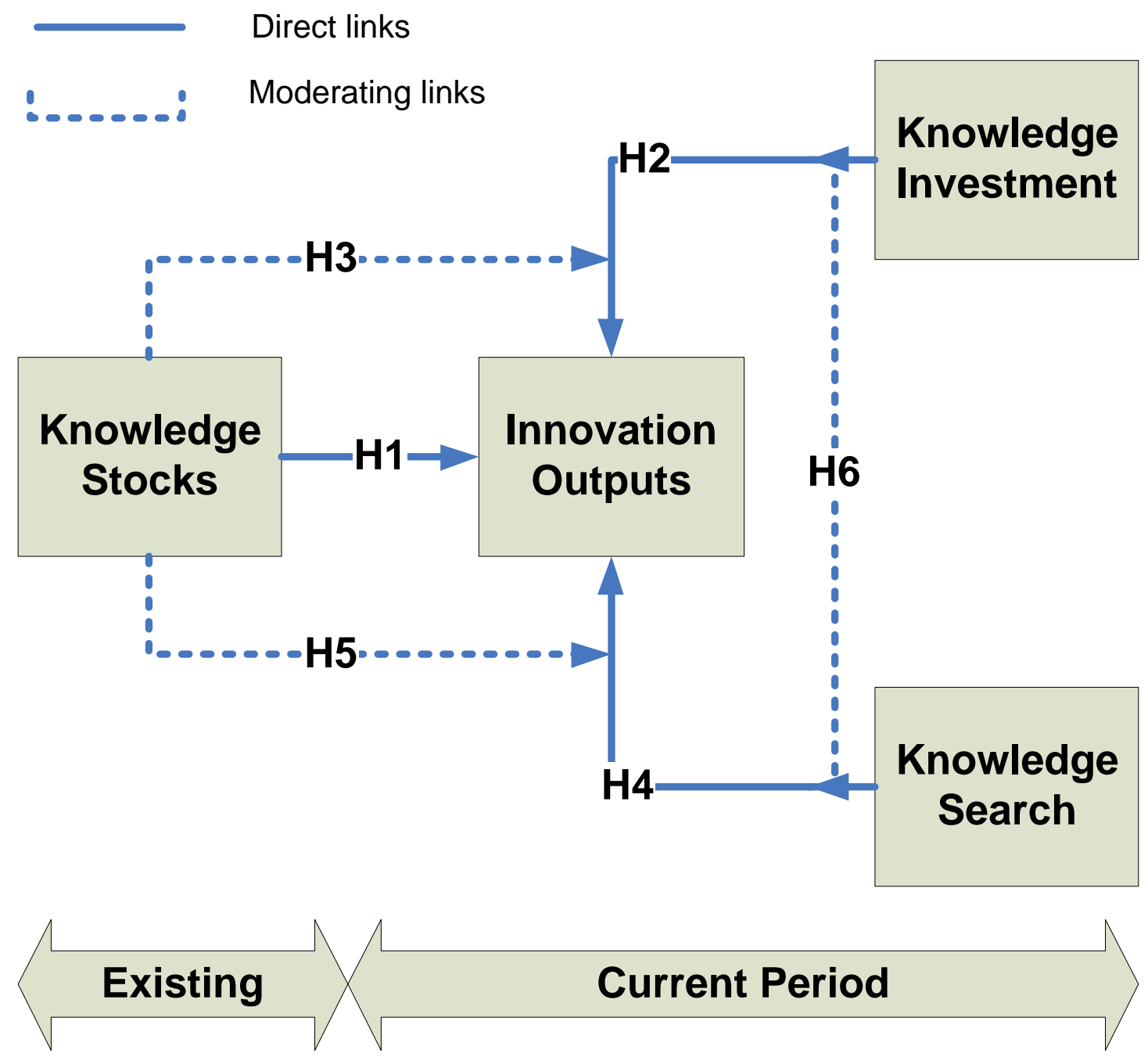


Figure 3: Percentage of innovating plants: By IIP Wave

A. Product and process innovation

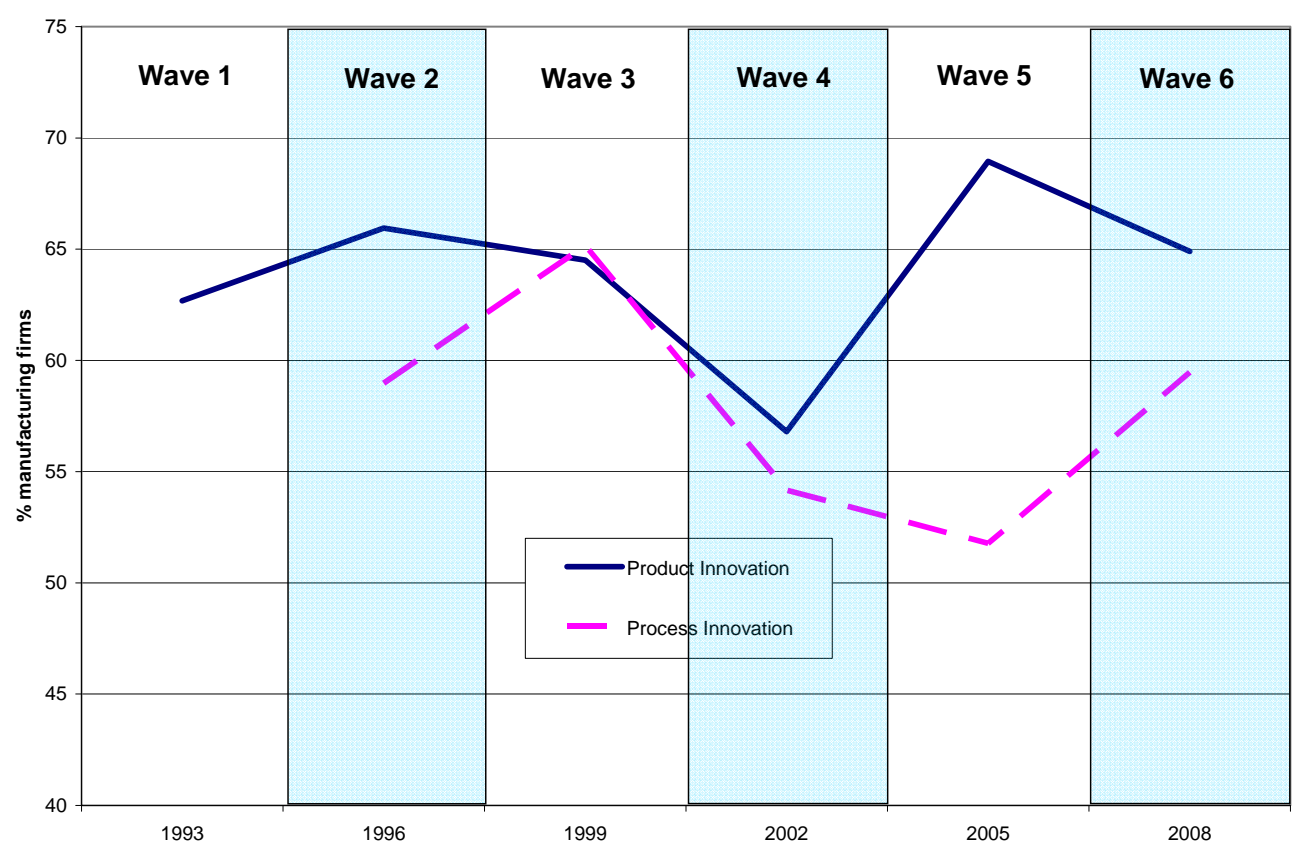

B: Percentage of sales from innovative products

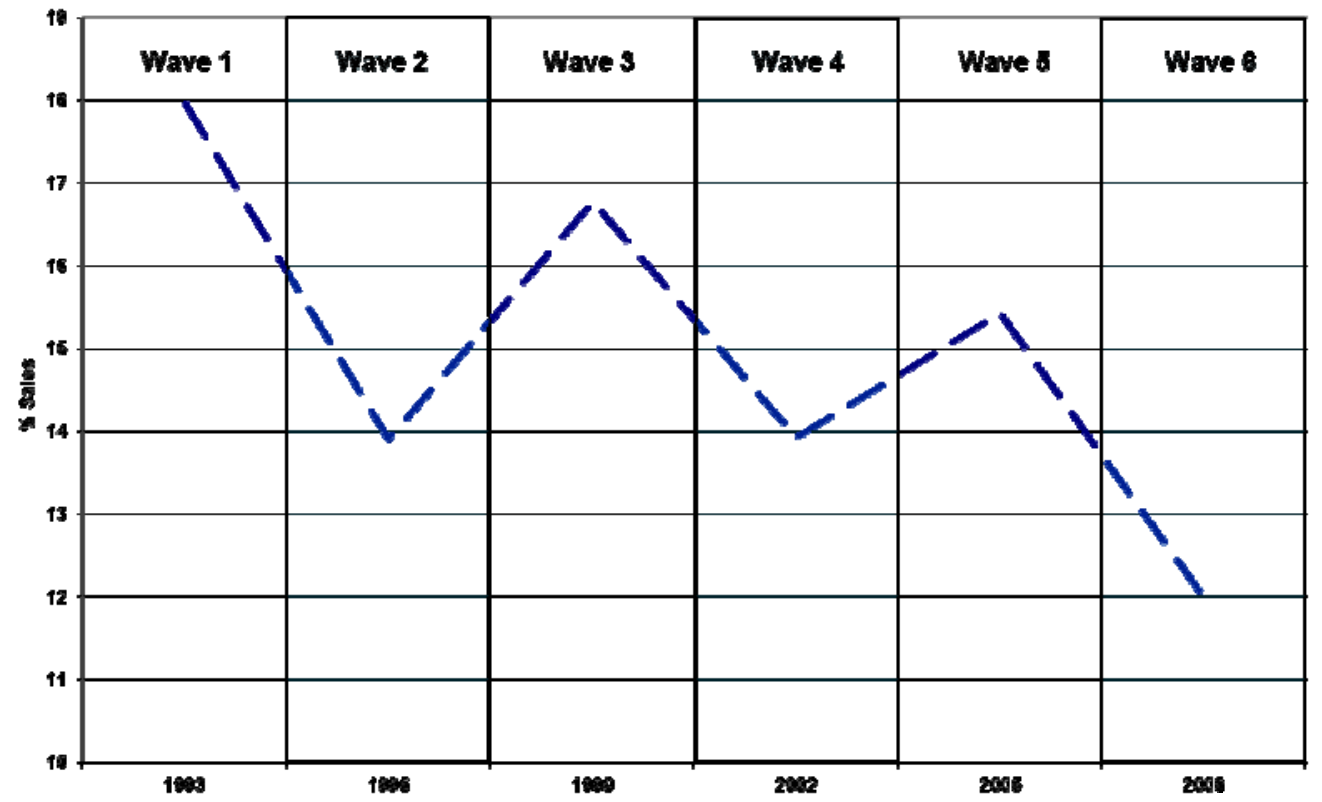

Source: Irish Innovation Panel 
Table 1: Descriptive Statistics

\begin{tabular}{|l|r|r|r|}
\hline & Obs & Mean & Std. Dev. \\
\hline Innovation indicators & & & \\
Product innovation (\% firms) & 2085 & 0.641 & 0.480 \\
Process innovation (\% firms) & 2054 & 0.581 & 0.494 \\
Sales of new products (\% sales) & 1945 & 14.700 & 22.408 \\
& & & \\
Knowledge sources & & & \\
Knowledge stock: Aggregate patent stock (mean per & 2085 & 0.362 & 4.746 \\
firm) & 2032 & 0.153 & 1.938 \\
Knowledge stock: Depr. patent stock (mean per firm) & 2032 & 0.131 & 1.065 \\
Knowledge stock: Depr. patent stock pe. (mean per & 2085 & 0.485 & 0.500 \\
100 employees) & 2041 & 1.336 & 1.934 \\
Knowledge investment: R\&D in-house (\% firms) & & & \\
Knowledge search: Innovation partners (avg per firm) & & & \\
& 2085 & 0.561 & 0.496 \\
Control variables & 2085 & 0.202 & 0.401 \\
Exporting firm & 2085 & 76.085 & 166.162 \\
R\&D department in house & 2085 & 3.339 & 36.371 \\
Site size (employment) & 2085 & 28.519 & 29.542 \\
Site age (years) & 2085 & 0.265 & 0.442 \\
Externally-owned site (\% firms) & 10.647 & 14.366 \\
Workforce with degree (\% workforce) & 2085 & & \\
Govt. support for product development (\% firms) & & & \\
\hline
\end{tabular}

Sources: IIP and Hewitt-Dundas et al., 2014 Observations are weighted to give representative results. Variable definitions in Annex 1. 
Table 2: Correlation Matrix

\begin{tabular}{|c|c|c|c|c|c|c|c|c|c|c|c|c|c|c|}
\hline | & & (1) & (2) & (3) & (4) & (5) & (6) & (7) & $(8)$ & (9) & $(10)$ & $(11)$ & $(12)$ & (13) \\
\hline (1) & Product innovation & 1.000 & & & & & & & & & & & & \\
\hline (2) & Process innovation & 0.267 & 1.000 & & & & & & & & & & & \\
\hline (3) & Innovative sales (new) & 0.510 & 0.165 & 1.000 & & & & & & & & & & \\
\hline (4) & Depreciated patent stock & 0.025 & -0.031 & 0.041 & 1.000 & & & & & & & & & \\
\hline (5) & R\&D in-house (\% firms) & 0.445 & 0.281 & 0.225 & 0.089 & 1.000 & & & & & & & & \\
\hline (6) & Innovation partnering & 0.268 & 0.316 & 0.203 & 0.061 & 0.302 & 1.000 & & & & & & & \\
\hline (7) & Exporting firm & 0.220 & 0.139 & 0.165 & 0.075 & 0.203 & 0.182 & 1.000 & & & & & & \\
\hline (8) & R\&D department in house & 0.297 & 0.168 & 0.241 & 0.113 & 0.515 & 0.288 & 0.262 & 1.000 & & & & & \\
\hline (9) & Enterprise size (employment) & 0.135 & 0.152 & 0.134 & 0.029 & 0.115 & 0.199 & 0.203 & 0.217 & 1.000 & & & & \\
\hline (10) & Site age (years) & 0.014 & -0.015 & -0.134 & -0.011 & -0.008 & 0.019 & -0.045 & -0.017 & 0.103 & 1.000 & & & \\
\hline (11) & Externally-owned site (\% firms) & 0.119 & 0.131 & 0.122 & 0.074 & -0.010 & 0.170 & 0.344 & 0.115 & 0.310 & -0.021 & 1.000 & & \\
\hline (12) & $\begin{array}{l}\text { Workforce with degree ( } \% \\
\text { workforce) }\end{array}$ & 0.112 & 0.008 & 0.146 & 0.270 & 0.118 & 0.138 & 0.168 & 0.213 & 0.122 & -0.003 & 0.191 & 1.000 & \\
\hline (13) & $\begin{array}{l}\text { Govt. support for product } \\
\text { development ( } \% \text { firms })\end{array}$ & 0.292 & 0.193 & 0.172 & 0.039 & 0.403 & 0.271 & 0.183 & 0.390 & 0.063 & -0.026 & -0.025 & 0.070 & 1.000 \\
\hline
\end{tabular}

Source: IIP and Hewitt-Dundas et al., 2014. Number of observations as Table 1. Variable definitions in Annex 1. 
Table 3: Innovation Production Functions: Probit models of product innovation

\begin{tabular}{|c|c|c|c|c|c|}
\hline & Model 1 & Model 2 & Model 3 & Model 4 & Model 5 \\
\hline \multicolumn{6}{|l|}{ Knowledge inputs to innovation } \\
\hline \multicolumn{6}{|l|}{ Knowledge Stock (patents per 100} \\
\hline employees) & & $\begin{array}{r}-0.051 \\
(0.041)\end{array}$ & & & $\begin{array}{r}-0.076 \\
(0.078)\end{array}$ \\
\hline \multirow[t]{2}{*}{ Knowledge Investment (R\&D) } & & & $1.261 * * *$ & & $1.295 * * *$ \\
\hline & & & $(0.103)$ & & $(0.120)$ \\
\hline \multirow[t]{2}{*}{ Knowledge Search } & & & & $0.413 * * *$ & $0.350 * * *$ \\
\hline & & & & $(0.060)$ & $(0.062)$ \\
\hline \multirow[t]{2}{*}{ Knowledge Search squared } & & & & $-0.043 * * *$ & $-0.028 * * *$ \\
\hline & & & & $(0.010)$ & $(0.010)$ \\
\hline \multicolumn{6}{|l|}{ Moderating effects } \\
\hline \multirow[t]{2}{*}{ Investment -Search } & & & & & $-0.124 * * *$ \\
\hline & & & & & $(0.047)$ \\
\hline \multirow[t]{2}{*}{ Stock-Investment } & & & & & -0.18 \\
\hline & & & & & $(0.112)$ \\
\hline \multirow[t]{2}{*}{ Stock-Search } & & & & & $0.077^{*}$ \\
\hline & & & & & $(0.039)$ \\
\hline \multicolumn{6}{|l|}{ Controls } \\
\hline \multirow[t]{2}{*}{ Exporting firm } & $0.383 * * *$ & $0.376 * * *$ & $0.318 * * *$ & $0.362 * * *$ & $0.277 * * *$ \\
\hline & $(0.089)$ & $(0.088)$ & $(0.090)$ & $(0.091)$ & $(0.090)$ \\
\hline \multirow[t]{2}{*}{ R\&D department in house } & $0.856 * * *$ & $0.876^{* * *}$ & $0.230 *$ & $0.801 * * *$ & $0.287 * *$ \\
\hline & $(0.129)$ & $(0.129)$ & $(0.133)$ & $(0.132)$ & $(0.136)$ \\
\hline \multirow[t]{2}{*}{ Plant size (employment) } & $0.001 * *$ & $0.001 * *$ & 0.000 & 0.001 & 0 \\
\hline & $(0.001)$ & $(0.001)$ & $(0.001)$ & $(0.001)$ & $(0.001)$ \\
\hline \multirow[t]{2}{*}{ Plant size squared (employment) } & -0.003 & -0.002 & 0.001 & -0.001 & 0.003 \\
\hline & $(0.003)$ & $(0.003)$ & $(0.005)$ & $(0.004)$ & $(0.006)$ \\
\hline \multirow[t]{2}{*}{ Plant age (years) } & 0.002 & 0.002 & 0.002 & 0.002 & 0.003 \\
\hline & $(0.002)$ & $(0.002)$ & $(0.002)$ & $(0.002)$ & $(0.002)$ \\
\hline \multirow[t]{2}{*}{ Externally-owned site } & $0.235 * *$ & $0.235 * *$ & $0.351 * * *$ & 0.166 & $0.291 * * *$ \\
\hline & $(0.107)$ & $(0.105)$ & $(0.108)$ & $(0.110)$ & (0.109) \\
\hline \multicolumn{6}{|l|}{ Workforce with degree $(\%$} \\
\hline workforce) & $\begin{array}{r}0.008 * * \\
(0.003)\end{array}$ & $\begin{array}{r}0.008 * * * \\
(0.003)\end{array}$ & $\begin{array}{c}0.006^{*} \\
(0.003)\end{array}$ & $\begin{array}{c}0.006^{*} \\
(0.003)\end{array}$ & $\begin{array}{r}0.005 \\
(0.003)\end{array}$ \\
\hline \multirow{2}{*}{$\begin{array}{l}\text { Govt. support for product } \\
\text { development }\end{array}$} & & & & & \\
\hline & $\begin{array}{r}0.911 * * * \\
(0.116)\end{array}$ & $\begin{array}{r}0.891 * * * \\
(0.116)\end{array}$ & $\begin{array}{r}0.568 * * * \\
(0.116)\end{array}$ & $\begin{array}{r}0.761 * * * \\
(0.119)\end{array}$ & $\begin{array}{r}0.456 * * * \\
(0.119)\end{array}$ \\
\hline \multirow[t]{2}{*}{ Constant term } & -0.038 & 0.020 & $-0.425 * * *$ & $-0.232 *$ & $-0.524 * * *$ \\
\hline & $(0.132)$ & $(0.132)$ & $(0.137)$ & $(0.137)$ & $(0.142)$ \\
\hline $\mathrm{N}$ & 2085 & 2032 & 2085 & 2041 & 1988 \\
\hline Chi2 & 231.046 & 227.477 & 287.63 & 240.815 & 271.117 \\
\hline $\mathrm{BIC}$ & 2718.6 & 2654.8 & 2527.3 & 2592.1 & 2387.475 \\
\hline
\end{tabular}

Source: IIP and Hewitt-Dundas et al., 2014. Variable definitions in Annex 1. All models include industry and wave dummy variables. Coefficients and standard errors are reported. ${ }^{*}$ denotes significance at the 10 per cent level; ** at 5 per cent and $* * *$ at the 1 per cent level. 
Table 4: Innovation Production Functions: Probit models of process innovation

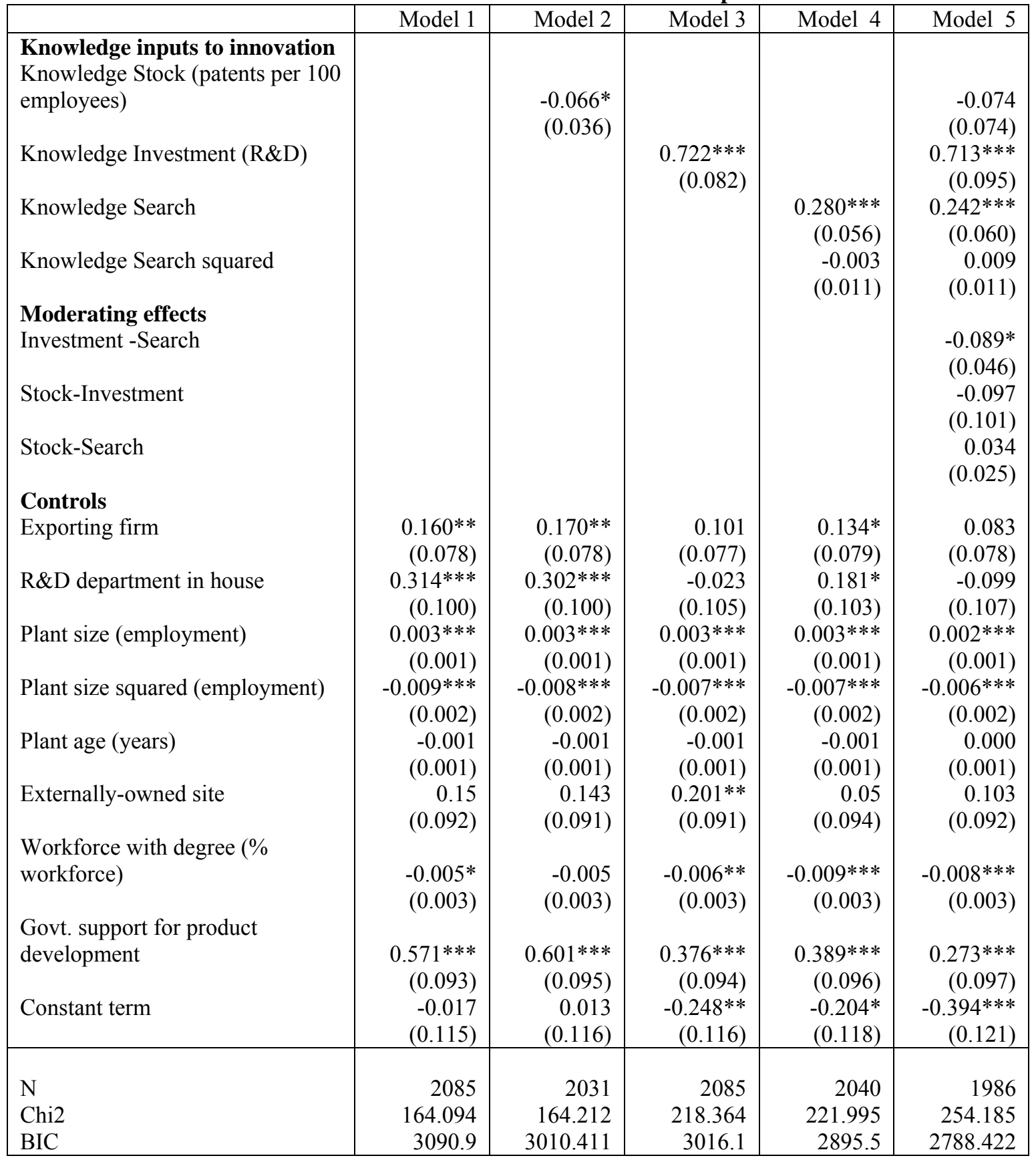

Source: IIP and Hewitt-Dundas et al., 2014. Variable definitions in Annex 1. All models include industry and wave dummy variables. Coefficients and standard errors are reported. $*$ denotes significance at the 10 per cent level; ** at 5 per cent and $* * *$ at the 1 per cent level. 
Table 5: Innovation Production Functions: innovative sales

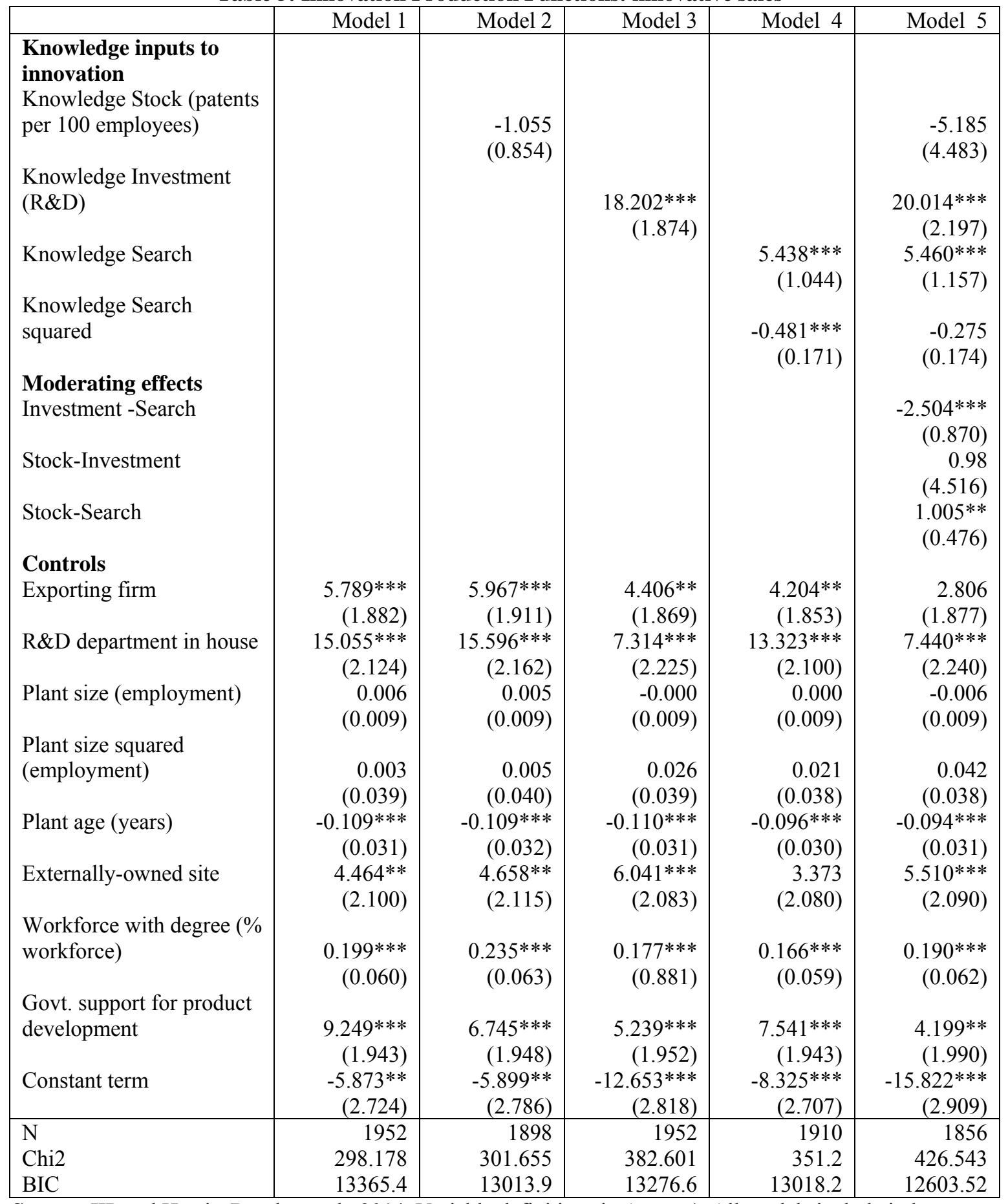

Source: IIP and Hewitt-Dundas et al., 2014. Variable definitions in Annex 1. All models include industry and wave dummy variables. Coefficients and standard errors are reported. $*$ denotes significance at the 10 per cent level; ** at 5 per cent and $* * *$ at the 1 per cent level. 
Table 6: Symbolic Summary of Results

\begin{tabular}{|l|c|c|c|c|}
\hline & $\begin{array}{c}\text { Anticipated } \\
\text { Effects }\end{array}$ & $\begin{array}{c}\text { Product } \\
\text { Innovation }\end{array}$ & $\begin{array}{c}\text { Process } \\
\text { Innovation }\end{array}$ & $\begin{array}{c}\text { Innovative } \\
\text { Sales }\end{array}$ \\
\hline $\begin{array}{l}\text { Knowledge inputs to innovation } \\
\text { H1: Knowledge stock }\end{array}$ & + & $(-)$ & $(-)$ & $(-)$ \\
H2: Knowledge investment & + & + & + & + \\
H3: Knowledge Search & + & + & + & + \\
Moderating effects & + & - & - & - \\
H4: Investment-Search & - & $(-)$ & $(-)$ & $(+)$ \\
H5: Stock-Investment & - & + & $(+)$ & + \\
H6: Stock-Search & & & & + \\
\hline
\end{tabular}

Notes: '-' denotes a negative and significant marginal effect (at the 10 per cent level or above); ' + ' denotes a positive and significant marginal effect; $(+)$ ' is an insignificant positive effect and (-) denotes an insignificant negative effect. 


\section{Innovation}

Product innovation $(0 / 1)$

Process innovation $(0 / 1)$

Innovative sales (new) (\% sales)

\section{Knowledge indicators} Absolute patent stock (number)

\section{Depreciated patent} stock (number)

In plant $\mathrm{R} \& \mathrm{D}$

Innovation Partnering

\section{Control variables}

Exporting firm

R\&D Department

Plant vintage

Externally owned
A binary variable taking value 1 if the firm introduced any new or improved product during the previous three years.

A binary variable taking value 1 if the firm introduced any new or improved process during the previous three years.

An indicator representing the percentage of firms' sales at the time of the survey accounted for by products which had been newly introduced over the previous three years.

The cumulative number of successful patent applications made by the firm in the period prior to the survey reference period.

The cumulative number of successful patent applications made by the firm in the period prior to the survey reference period depreciated using the estimated depreciation rates from Park and Park (2006).

A binary indictor taking value one if the firm has an in-house $R \& D$ capacity

An indicator of the number of the breadth of innovation partnering conducted by the firm. Takes values 0 to 10 depending on how many different types of partner firm is working with: group company, supplier, consultant, client, competitor, joint venture, government laboratory, university, private laboratory, industry research centre.

A binary indicator taking value one if the firm was selling outside the UK and Ireland.

A binary indictor taking value one if the firm had a formally organised internal $R \& D$ department.

The age of the site (in years) at the time of the survey.

A binary indicator taking value one if the firm was owned outside Ireland at the time of the survey. 


\begin{tabular}{|l|l|}
\hline $\begin{array}{l}\text { Employment } \\
\text { Percentage with degree }\end{array}$ & $\begin{array}{l}\text { Employment at the time of the survey. } \\
\text { Percentage of the workforce with a degree or } \\
\text { equivalent qualification }\end{array}$ \\
$\begin{array}{l}\text { Public support for } \\
\text { product innovation }\end{array}$ & $\begin{array}{l}\text { A binary indicator taking value one if the firm had } \\
\text { received government support for product innovation } \\
\text { over the previous three years. }\end{array}$ \\
\hline
\end{tabular}




\section{References}

Advisory Committee on Measuring Innovation in the 21st Century Economy. 2008. Innovation Measurement - Tracking the state of innovation in the US economy $A$ report to the Secretary of Commerce.

Ahuja, G. and R. Katila. 2001. Technological Acquisitions and the Innovation Performance of Acquiring Firms: A Longitudinal Study. Strategic Management Journal 22:197-220.

Arora, A. and A. Gambardella. 1990. Complementarity and external linkages: the strategies of the large firms in biotechnology. Journal of Industrial Economics 38:361-379.

Artz, K.W., P.M. Norman, D.E. Hatfield, and L.B. Cardinal. 2010. A Longitudinal Study of the Impact of R\&D, Patents, and Product Innovation on Firm Performance. Journal of Product Innovation Management 27:725-740.

Arvanitis, S., H. Hollenstein; U. Kubli, N. Sydow, and M. Wörter. 2007. Innovationstätigkeit in der Schweizer Wirtschaft. Strukturberichterstattung Nr. 24, Staatssekretariat für Wirtschaft (seco) (ed.). Bern.

Atkeson, A. and P.J. Kehoe. 2005. Modelling and Measuring Organization Capital. Journal of Political Economy 113:1026-1053.

Audretsch, D.B. 2002. The Dynamic Role of Small Firms: Evidence from the U.S. Small Business Economics 18:13-40.

Barry, F. 2005. FDI, Transfer Pricing and the Measurement of R\&D-Intensity. Research Policy 34:673-681.

Belderbos, R., M. Carree, and B. Lokshin. 2006. Complementarity in R\&D cooperation strategies. Review of Industrial Organization 28:401-426.

Bergek, A., C. Berggren, T. Magnusson, and M. Hobday. 2013. Technological discontinuities and the challenge for incumbent firms: destruction, disruption or creative accumulation? Research Policy, 42, 6-7, 1210-1224.

Berry, W.D., J.H.R. DeMeritt, and J. Esarey. 2010. Testing for Interaction in Binary Logit and Probit Models: Is a Product Term Essential? American Journal of Political Science 54:248-266.

Brouwer, E. and A. Kleinknecht. 1999. Innovative output, and a firm's propensity to patent. An application of CIS micro data. Research Policy 28:615-624.

Buiseret, T., H.M. Cameron, and L. Georgiou. 1995. What differences does it make? Additionality in the public support of R\&D in large firms. International Journal Of Technology Management 10:587-600.

Cassiman, B. and R. Veugelers. 2002. Complementarity in the Innovation strategy: Internal R\&D, External technology acquisition and co-operation in R\&D. In EARIE Annual Conference. Madrid.

Cassiman, B. and R. Veugelers. 2006. In Search of Complementarity in Innovation Strategy:Cooperation in R\&D Internal R\&D and External Technology Acquisition Management Science \& Public Policy 52:68-82.

Cefis, E. and L. Orsenigo. 2001. The Persistence of Innovative Activities; A Cross Country and Cross-Sectors Comparative Analysis. Research Policy, 30:11391158.

Chesborough, H.W. 2003. Open Innovation. Harvard University Press. 
2006. Open Innovation: a new paradign for understanding industrial innovation. Oxford: Oxford University Press.

Choo, C.W. and N. Bontis. 2002. The Strategic Management of Intellectual Capital and Organizational Knowledge. Oxford: Oxford University Press.

Cohen, W.M. and D.A. Levinthal. 1990. Absorptive capacity: a new perspective on learning and innovation. Administrative Science Quarterly 35:128-152.

Crepon, A., A. Hughes, P. Lee, and J. Mairesse. 1998. Research, Innovation and Productivity: An econometric analysis at the firm level. Economics of Innovation and New Technology 7:115-158.

de Rassenfoss, G. and B. van Pottelsberghe. 2009. A policy insight into the R\&D-patent relationship. Research Policy 38:779-792.

Dierickx, I. and K. Cool. 1989. Asset stock accumulation and sustainabilty of competitive advantage. Management Science 35:1504-1511.

Escribano, A., A. Fosfuri, J.A. Tribó. 2009. Managing external knowledge flows: The moderating role of absorptive capacity. Research Policy, 39, 96-105.

Faber, J. and A.B. Hensen. 2004. Innovation capabilities of European nations - Crossnational analysis of patents and sales of product innovations. Research Policy 33:193-207.

Fleming, L. and D.M. Waguespack. 2007. Brokerage, boundary spanning, and leadership in open innovation communities. Organization Science 18:165-180.

Freel, M.S. 2005. Patterns of Innovation and skills in small firms. Technovation 25:123134.

Griffith, R., S. Redding, and J. Van Reenan. 2003. R\&D and Absorptive Capacity: Theory and Empirical Evidence. Scandinavian Journal of Economics 105:99-118.

Griliches, Z. 1995. R\&D and Productivity: Econometric Results and Measurement Issues. Oxford: Blackwell.

Guellec, D. and B. van Pottelsberghe. 2004. From R\&D to productivity growth: do the institutional settings and the source of funds matter? Oxford Bulletin of Economics and Statistics 66:353-378.

Hansen, M.T. and J. Birkinshaw. 2007. The Innovation Value Chain. Harvard Business Review June 121-130.

Haskel, J., T. Clayton, P. Goodridge, A. Pesole, D. Barnett, G. Chamberlin, R. Jones, K. Khan, and A. Turvey. 2009. Innovation, knowledge spending and productivity growth in the UK Interim report for NESTA Innovation Index project: NESTA

Heger, D. and A.K. Zaby. 2013. The heterogeneous costs of disclosure and the propensity to patent. Oxford Economic Papers-New Series 65:630-652.

Helfat, C. 1994. Firm-specificity in corporate applied R\&D. Organisation science 5:173184.

Hewitt-Dundas, N. and S. Roper. 2008. Ireland's Innovation Performance: 1991-2005. Quarterly Economic Commentary, ESRI, Dublin.:46-68

Hewitt-Dundas, N. and S. Roper. 2009. Output Additionality of Public Support for Innovation: Evidence for Irish Manufacturing Plants. European Planning Studies 18:107-122.

Hewitt-Dundas, N., A. Singh, Y.P. Ho, and P.K. Wong. 2014. Knowledge Flows Of Innovation In Small Open Economies - Comparative Analysis Of Ireland And Singapore, forthcoming Research Policy.

Hoetker, G. 2007. The use of logit and probit models in strategic management research: Critical issues. Strategic Management Journal 28:331-343.

Horn, P.M. 2005. The Changing Nature of Innovation. Research Technology Management 48:28-33. 
Hung, K-P., C. Chou. 2013. The impact of open innovation on firm performance: The moderating effects of internal R\&D and environmental turbulence. Technovation, 33, 10-11, 368-380.

Hutzschenreuter, T. and S. Israel. 2009. A review of empirical research on dynamic competitive strategy. International Journal of Management Reviews 11:421-461.

Jensen, C. 2004. Localized spillovers in the Polish food industry: The role of FDI in the development process? Regional Studies 38:535-550.

Jordan, D. and E. O'Leary. 2007. Sources of innovation in Irish SMEs: Evidence from two Irish regions. In British-Irish Regional Science Association Annual Conference. Bangor.

Katila, R and G. Ahuja. 2002. Something old, something new; a longitudinal study of search behaviour and new product introduction. Academy of management journal. 45, 6, $1183-1194$.

Klette, T.J. and F. Johansen. 1998. Accumulation of R\&D Capital and Dynamic Firm Performance: a not-so-Fixed Effect Model. Annales de Economie et de Statistique 49-50:389-419.

Kyriakopoulos, K. and K. de Ruyter. 2004. Knowledge Stocks and Information Flows in New Product Development. Journal of Management Studies 41:1469-1498.

Laursen, K. and A. Salter. 2006. Open for Innovation: The role of openness in explaining innovation performance among UK manufacturing firms. Strategic Management Journal 27:131-150.

Lee, C.Y. 2010. A theory of firm growth: Learning capability, knowledge threshold, and patterns of growth. Research Policy 39:278-289.

Leiponen, A. 2005. Skills and innovation. International Journal of Industrial Organization 23:303-323.

Leonard-Barton, D. 1992. Core capabiliteis and core rigidities: a paradox in managing new product development. Strategic Management Journal 13:111-125.

Levinthal, D. and J. March. 1993. The myopia of learning. Strategic Management Journal:95-112.

Loof, H. and A. Heshmati. 2001. On the Relationship between Innovation and Performance: A Sensitivity Analysis. Stockholm School of Economics. . 2002. Knowledge capital and performance heterogeneity: A firm level innovation study. International Journal of Production Economics 76:61-85.

Love, J.H. and S. Roper. 2001. Networking and Innovation Success: A Comparison of UK, German and Irish Companies. Research Policy 30:643-661. . 2004. The Organisation of Innovation: Collaboration, Co-operation and Multifunctional Groups in UK and German Manufacturing. Cambridge Journal of Economics 28:379-395.

Lucas, H.C. and J.M. Goh. 2009. Disruptive technology: How Kodak missed the digital photography revolution. Journal of Strategic Information Systems 18:46-55.

Mainwaring, L., N. Moore, and P.D. Murphy. 2007. A regional comparison of enterprise patent holdings: A study of British and Irish data. Research Policy 36:1655-1665.

Mansfield, E. 1986. Patents and innovation: an empirical study. Management Science 32:173-181.

March, J.G. 1991. Exploration and Exploitation in Organisational Learning. Organisation science 2.

McCarthy, F.D. 2001. Social Policy and macroeconomics: The Irish experience, . In Policy Research Working Paper Series No. 2736: The World Bank. 
Meehan, E. 2000. Britain's Irish Question: Britain's European Question?: British-Irish relations in the context of the European Union and the Belfast Agreement. Review of International Studies 26:83-97.

Norton, E.C., H. Wang, and C. Ai. 2004. Computing interaction effects and standard errors in logit and probit models Stata Journal 4:154-167.

O'Malley, E., S. Roper, and N. Hewitt-Dundas. 2008. High growth and innovation with low R\&D: The case of Ireland. In Small Economy Innovation System; Comparing Globalization, Change and Policy in Asia and Europe, ed. C. Edquist and L. Hommen: Elgar.

O'Sullivan, M. 2000. The sustainability of industrial development in Ireland. Regional Studies 34:277-290.

Oerlemans, L., M. Meeus, and F. Boekema. 1998. Do networks matter for innovation? The usefulness of the economic network approach in analysing innovation. Tijdschrift voor Economische en Sociale Gcografie 89:298-309.

Park, G. and Y. Park. 2006. On the measurement of patent stock as knowledge indicators. Technological Forecasting And Social Change 73:793-812.

Peeters, C. and B. Van Pottelsberghe. 2006. Innovation strategy and the patenting behaviour of firms Journal Of Evolutionary Economics 16:109-135.

Penin, J. 2005. Patents versus ex post rewards: a new look. Research Policy 34:641-656.

Perez-Cano, C. and J. Villen-Altamirano. 2013. Factors that Influence the Propensity to Patent. Emj-Engineering Management Journal 25:27-38.

Ramani, S.V., M.-A. El-Aroui, and M. Carrere. 2008. On estimating a knowledge production funtion at the firm and sector level using patent statistics. Research Policy 37:1568-1578.

Rodriguez-Pose, A. 2001. Is R\&D investment in leading areas of Europe worthwhile? Theory and empirical evidence. Papers in Regional Science 80:275-295.

Roper, S. 2001. Innovation, Networks and Plant Location; Evidence for Ireland. Regional Studies 35:215-228.

Roper, S. and J. Anderson. 2000. Innovation and E-Commerce - A Cross-Border Comparison of Irish Manufacturing Plants. Belfast.

Roper, S., J. Du, and J.H. Love. 2008. Modelling the Innovation Value Chain. Research Policy 37:961-977.

Roper, S. and N. Hewitt-Dundas. 1998. Innovation, Networks and the Diffusion of Manufacturing Best Practice: A Comparison of Northern Ireland and the Republic of Ireland. Belfast: NIERC.

Roper, S. and N. Hewitt-Dundas. 2008. Innovation Persistence: Survey and Case-Study Evidence. Research Policy 37:149-162.

Roper, S. and N. Hewitt-Dundas. 2012. Does additionality persist? A panel data investigation of the legacy effects of public support for innovation? In DRUID. Copenhagen.

Roper, S.; N. Hewitt-Dundas, and M. Savage. 2003. Innovation, Best Practice Adoption and Innovation Networks - A Comparison of Northern Ireland and the Republic of Ireland, ed. N.I.E.R. Centre. Belfast.

Roper, S.; J. Youtie, P. Shapira, and A. Fernandez-Ribas. 2010. Knowledge, Capabilities and Manufacturing Innovation: A US-Europe Comparison'. Regional Studies 44, 3:253-279.

Roper, S., B. Ashcroft, J.H. Love, S. Dunlop, H. Hofmann and K.Vogler-Ludwig. 1996. Product Innovation and Development in UK, German and Irish Manufacturing: Queen's University of Belfast/University of Strathclyde/info Institut. 
Santamaria, L., M.J. Nieto, and A. Barge-Gil. 2009. Beyond formal R\&D: Taking advantage of other sources of innovation in low- and medium-technology industries. Research Policy 38:507-517.

Schafer, J.L. 1997. Analysis of Incomplete Multivariate Data. London.: Chapman \& Hall. Smith, D.J. and D. Tranfield. 2005. Talented suppliers? Strategic change and innovation in the UK aerospace industry. $R \& D$ Management 35:37-49.

Su, C.T., Y.H. Chen, and D.Y.J. Sha. 2007. Managing product and customer knowledge in innovative new product development. International Journal Of Technology Management 39:105-130.

Teece, D. 1998. Capturing value from knowledge assets: the new economy, markets for know-how and intangible assets. California Management Review, 40, 3, 55-79.

Thrane, S., S. Blaabjerg, and R.H. Moller. 2010. Innovative path dependence: Making sense of product and service innovation in path dependent innovation processes. Research Policy 39:932-944.

Trajtenberg, M. 2001. Innovation in Israel 1968-1997: a comparative analysis using patent data. Research Policy 30:363-389.

Tzabbar, D., B.S. Aharonson, T.L. Amburgey, and A. Al-Laham. 2008. When is the whole bigger than the sum of its parts? Bundling knowledge stocks for innovative success. Strategic Organization 6:375-406.

Ulku, H. 2007. R\&D, innovation, and growth: evidence from four manufacturing sectors in OECD countries. Oxford Economic Papers-New Series 59:513-535.

Veugelers, R. and B. Cassiman. 1999. Make and Buy in Innovation Strategies: Evidence from Belgian manufacturing firms. Research Policy 28:63-80.

West, J. and S. Gallagher. 2006. Challenges of open innovation: the paradox of firm investment in open-source software. $R \& D$ Management 36:319-331.

Wu, J.F. and M.T. Shanley. 2009. Knowledge stock, exploration, and innovation: Research on the United States electromedical device industry. Journal of business research 62:474-483.

Zahra, S.A. and G. George. 2002. Absorptive capacity: a review, re-conceptualization, and extension. Academy of management review 27:185-203.

Zenger, T. 2002. Crafting internal hybrids: complementarities, common change initiatives and the team-based organisation. International Journal of the Economics of Business 9:79-95. 